\title{
STUDI TERAPI ANTIRETROVIRAL PADA PASIEN HIV/AIDS DI KOTA SAMARINDA
}

\author{
Nur Riska Safitri ${ }^{1, \dagger}$, Jaka Fadraersada ${ }^{1,2}$, Rolan Rusli ${ }^{1,3, \ddagger}$ \\ ${ }^{1}$ Laboratorium Penelitian dan Pengembangan Kefarmasian "Farmaka Tropis", \\ Fakultas Farmasi, Universitas Mulawarman, Samarinda, Indonesia \\ †Email: Nurriskasftr@gmail.com \\ ${ }^{2}$ Kelompok Bidang Ilmu Farmasi Klinik dan Komunitas, Fakultas Farmasi, \\ Universitas Mulawarman, Samarinda, Indonesia \\ ${ }^{3}$ Kelompok Bidang Ilmu Kimia Farmasi, Fakultas Farmasi, Universitas Mulawarman, \\ Samarinda, Indonesia. \\ *Email: rolan@farmasi.unmul.ac.id
}

\begin{abstract}
Human immunodeficiency virus (HIV) is a virus that attacks or infects the human immune system. There are 4 stages of HIV infection when the virus reaches stage 4, called Acquired Immune Deficiency Syndrome (AIDS). Antiretroviral therapy is a therapy given to people with HIV/AIDS that must be consumed for life. The purpose of this study was to determine the characteristics and treatment patterns of HIV/AIDS patients in Samarinda. observational method was used to collect the data retrospectively and analyzed descriptively from patients with HIV/AIDS in hospitals and several health centers in Samarinda. The observational study shows 233 people, with the highest characteristics, respectively: 173 male sex (74.2\%), 25 to 49 years old age (72.5\%), private employment $(57.9 \%)$ and high school education (21,4\%). Most HIV/AIDS treatments that used by patients in samarinda is antiretroviral triple FDC combination drug regimens (Tenofovir $300 \mathrm{mg}+$ Lamivudin $300+$ Efavirenz 600.
\end{abstract}

Keywords : AIDS, Antiretroviral, HIV, Triple FDC

\begin{abstract}
ABSTRAK
Human immunodeficiency virus (HIV) adalah virus yang menyerang atau menginfeksi sistem imun yang menyebabkan turunnya kekebalan tubuh manusia. Ada 4 stadium infeksi HIVdimana pada saat virus ini mencapai stadium 4 disebut dengan Acquired Immuno Deficiency Syndrome (AIDS). Terapi antiretroviral merupakan terapi yang diberikan untuk orang dengan HIV/AIDS yang harus dikonsumsi seumur hidup. Tujuan penelitian ini adalah mengetahui karakteristik serta pola pengobatan pasien HIV/AIDS yang ada di kota Samarinda. Metode yang digunakan ialah observasional dengan pengumpulan data secara retrospektif pada pasien HIV/AIDS di rumah sakit dan beberapa puskesmas di kota Samarinda dan kemudian dianalisis secara deskriptif. Hasil studi observasional menunjukkan total penderita sebesar 233 orang, dengan karakteristik terbanyak, yaitu: berjenis kelamin laki-laki $173(74,2 \%)$, rentang usia 25 s.d 49 tahun (72,5\%), pekerjaan
\end{abstract}


swasta $(57,9 \%)$ dan pendidikan SMA $(21,4 \%)$. Pengobatan HIV/AIDS di kota Samarinda sebagian besar menggunakan antiretroviral regimen obat kombinasi Triple FDC (Tenofovir 300 mg + Lamivudin 300 + Efavirenz 600).

Kata Kunci: AIDS, Antiretroviral, HIV, Triple FDC

DOI: https://doi.org/10.25026/mpc.v9i1.342

\section{PENDAHULUAN}

Human immunodeficiency virus (HIV) adalah virus yang menyerang atau menginfeksi sistem imun yang menyebabkan turunnya kekebalan tubuh manusia. Infeksi HIV ini terbagi menjadi 4 stadium dimana pada saat virus ini mencapai stadium 4 disebut dengan Acquired Immuno Deficiency Syndrome (AIDS) dan AIDS ini biasanya ditandai dengan adanya infeksi oportunistik (IO). Terapi antiretroviral merupakan terapi yang diberikan untuk orang dengan HIV/AIDS yang harus dikonsumsi seumur hidup [1,2].

Jumlah Kasus HIV di Indonesia sejak tahun 1987 sampai dengan Maret 2018 di seluruh Indonesia adalah 291.129 kasus. Jumlah kasus HIV di Provinsi Kalimantan Timur pada tahun 1987 sampai Maret 2018 menduduki peringkat 12 dengan jumlah total 5.545 kasus. Jumlah kasus AIDS di Indonesia sampai dengan Maret 2018 adalah 106.965. Provinsi Kalimantan Timur menduduki peringkat ke 15 dengan total 1.433 kasus AIDS [3].

Mayoritas pasien HIV/AIDS menurut penelitian yang ada yaitu penderita yang berada pada usia produktif, dengan rentang usia 26-35 dan 36-45 tahun yang pravelensinya mencapai lebih dari $70 \%$. Hal ini juga berlaku secara nasional berdasarkan data Yayasan Spiritia tahun 2016 yang menunjukkan bahwa $82 \%$ penderita AIDS berasal dari kelompok umur 20-50 tahun, dengan persentase terbesar berada pada rentang usia 30-39 tahun [4].
Sampai saat ini HIV/AIDS belum bisa disembuhkan namun infeksi dan replikasi HIV masih bisa dicegah dengan obat. Pengobatan tersebut dikenal dengan terapi antiretroviral. Terapi antiretroviral merupakan terapi yang dijalankan orang dengan HIV/AIDS (ODHA) dengan cara mengonsumsi obat seumur hidup. Tujuannya untuk menekan replikasi HIV dalam tubuh. Terapi antiretroviral juga merupakan gabungan dari tiga macam obat yang dinyatakan bermanfaat untuk terapi AIDS sejak tahun 1996 [5].

Berdasarkan latar belakang di atas, maka peneliti ingin meneliti tentang terapi antiretroviral yang diberikan kepada pasien HIV/AIDS. Sehingga dapat menambah informasi dan pengetahuan tentang terapi yang tepat dan efektif untuk diberikan kepada pasien HIV/AIDS serta tidak memperparah penularan secara luas HIV/AIDS.

\section{METODE PENELITIAN}

Metode yang digunakan ialah observasional dengan pengumpulan data secara retrospektif yaitu dengan melihat data rekam medis pasien HIV/AIDS. Data yang diambil berupa karakteristik pasien serta pola pengobatan yang diberikan kepada pasien HIV/AIDS. Penelitian ini dilakukan di RSUD. Abdul Wahab Sjahranie Samarinda dan beberapa puskesmas di kota Samarinda. Teknik pengambilan sampel pada penelitian ini menggunakan teknik total sampling. Dengan jumlah populasi 233 pasien di rumah sakit dan puskesmas kota Samarinda. Bahan pada penelitian ini 
ialah rekam medis kesehatan pasien yang kemudian akan dianalisis secara deskriptif.

\section{HASIL DAN PEMBAHASAN}

Berdasarkan hasil penelitian didapatkan 233 populasi pasien HIV/AIDS di RSUD Abdul Wahab Sjahranie dan beberapa puskesmas di kota Samarinda dengan karakteristik yang dapat dilihat pada tabel 1.

Data pada penelitian ini menunjukkan bahwa mayoritas penderita HIV/AIDS terbanyak terdapat pada jenis kelamin laki-laki yaitu sebanyak 173 orang $(74,2 \%)$ dibandingkan dengan jenis kelamin perempuan yang jumlahnya hanya 60 orang $(25,7 \%)$. Hal ini sesuai dengan penelitian sebelumnya yang dilakukan di RSUP Sanglah Denpasar terhadap 179 pasien HIV/AIDS yang menyatakan bahwa jumlah penderita HIV/AIDS laki-laki (67,6\%) lebih banyak dibandingkan dengan perempuan $(32,4 \%)$ [6]. Kedua penelitian ini sesuai dengan laporan Kemenkes bahwa persentase penderita HIV/AIDS laki-laki 2 kali lebih banyak dibandingkan penderita HIV/AIDS perempuan [3].

Tingginya persentase penderita HIV/AIDS berjenis kelamin laki-laki ini diasumsikan terjadi akibat dari penularan melalui pekerja seks komersial (PSK) yang dapat menularkan HIV/AIDS kepada setiap partnernya. Salah satu hal lain yang juga menjadi kontribusi tingginya angka kejadian infeksi HIV pada laki-laki yaitu meningkatnya kecenderungan praktek lelaki seks lelaki (LSL). Hal ini didukung dengan laporan Kemenkes RI dimana resiko penularan terbesar adalah melalui homoseksual dan heteroseksual. Serta penggunaan narkoba suntik yang bisa menyebabkan terjadinya HIV/AIDS [3].

Berdasarkan usia persentase terbesar penderita HIV/AIDS adalah pada kelompok usia 25-49 tahun yaitu berjumlah 169 orang $(72,5 \%)$, kemudian disusul kelompok usia 20-24 tahun yaitu sebanyak 41 orang $(17,5 \%)$, dan kelompok umur $\geq 50$ tahun yaitu sebanyak 18 orang $(7,7 \%)$. Hal ini sesuai dengan laporan Kemenkes RI bahwa persentase pasien HIV/AIDS terbanyak yaitu pada kelompok usia 25-49 tahun (71,8\%), disusul kelompok usia 20-24 tahun $(13,6 \%)$, dan kelompok usia $\geq 50$ tahun $(8,5 \%)$ [3].

Pada perjalanannya seseorang yang tertular HIV hingga menjadi AIDS dapat berlangsung dengan waktu yang lama. Penderita yang didiagnosis pada usia 30-40 tahun sudah terpapar HIV pada saat remaja akhir dan dewasa awal. Berdasarkan yang dijelaskan seseorang bahwa infeksi HIV ternyata lebih banyak terjadi pada usia muda ketimbang usia tua. Hal ini disebabkan pada usia muda lebih mungkin banyak melakukan perilaku seks tidak aman yang sangat berisiko dalam penularan infeksi HIV. Perilaku seks tidak aman yang dimaksud misalnya berhubungan seks yang berganti-ganti pasangan tanpa menggunakan kondom dan tidak hanya itu ada pula kemungkinan rasa ingin mencoba-coba serta adanya keinginan untuk mengkonsumsi narkoba [6,7].

Data pada penelitian ini juga memperlihatkan bahwa penderita HIV/AIDS terbanyak yaitu pada pendidikan SMA sebanyak 50 orang $(21,4 \%)$, disusul oleh pendidikan SMP sebanyak 20 orang $(8,5 \%)$, dan pendidikan SD sebanyak 7 orang $(3,0 \%)$. Hasil penelitian ini sesuai dengan penelitian yang dilakukan seseorang di Sumba Timur yang menyatakan penderita terbanyak yaitu pada pendidikan SMA sebanyak 54 orang $(48,6 \%)$ dan kemudian disusul dengan pendidikan SMP sebanyak 27 orang $(24,3 \%)$, SD sebanyak 22 orang $(19,8)$ [9].

Tingkat pendidikan berpengaruh terhadap perilaku yang lebih baik. Seseorang yang mempunyai tingkat pendidikan seharusnya mempunyai wawasan yang luas sehingga dapat menjadi teladan. Tetapi pada penelitian 
ini terdapat banyak pasien dengan tingkat pendidikan SMA yang terinfeksi virus HIV, jadi bisa diasumsikan bahwa tingkat pendidikan yang tinggi tidak menjamin bahwa seseorang telah mengetahui tentang bahayanya infeksi virus HIV.

Hasil pada penelitian ini menunjukkan penderita HIV/AIDS berdasarkan pekerjaan paling tinggi pada pegawai swasta yaitu 135 orang $(57,9 \%)$, disusul dengan ibu rumah tangga yaitu sebanyak 27 orang $(11,5 \%)$ dan kemudian wanita pekerja seks (WPS) sebanyak $17(7,2 \%)$. Hasil penelitian ini sedikit berbeda dengan penelitian yang dilakukan di RSUP Sanglah Denpasar yang menyatakan penderita HIV/AIDS terbanyak dengan pekerjaan pegawai swasta dengan persentase $43 \%$, disusul dengan penderita dengan pekerjaan wiraswasta $12,8 \%$, dan ibu rumah tangga 9,5\% [6]. Penelitian ini juga sedikit berbeda dengan laporan dari Kemenkes tentang jumlah kumulatif AIDS (tahun 1987 s.d Maret 2018) terbanyak menurut pekerjaan yaitu ibu rumah tangga $(15,162)$, disusul tenaga non professional/karyawan $(14,665)$ dan wiraswasta (14,085) [3]. Meskipun demikian dari hasil penelitian tersebut dapat kita asumsikan bahwa orang yang bekerja dan memiliki penghasilan sendiri cenderung dapat menjadi pendorong untuk seseorang melakukan sesuatu yang dia inginkan misalnya membeli seks yang sebenarnya merupakan sebuah perilaku yang bisa membuat dia rentan untuk terinfeksi HIV serta menkonsumsi narkoba, kemudian ada pula yang tidak bekerja tetapi terinfeksi HIV seperti yang terjadi pada ibu rumah tangga. Hal ini diduga ditularkan dari suaminya yang menderita HIV/AIDS..

Tabel 1. Karakteristik Pasien berdasarkan Jenis Kelamin, Usia, Pendidikan dan Pekerjaan

\begin{tabular}{lccc}
\hline \multicolumn{2}{c}{ Karakteristik } & Jumlah Pasien & Persentase (\%) \\
\hline Jenis Kelamin & Laki-laki & 173 & 74,2 \\
& Perempuan & 60 & 25,7 \\
\hline Usia & $15-19$ tahun & 5 & 2,1 \\
& $20-24$ tahun & 41 & 17,5 \\
& $25-49$ tahun & 169 & 72,5 \\
& $\geq 50$ tahun & 18 & 7,7 \\
\hline Pendidikan & SD & 7 & 3,0 \\
& SMP & 20 & 8,5 \\
& SMA & 50 & 21,4 \\
& D1 & 1 & 0,4 \\
& D3 & 3 & 1,2 \\
& S1 & 4 & 1,7 \\
& Tidak diketahui & 148 & 63,5 \\
\hline Pekerjaan & Pegawai Swasta & 135 & 57,9 \\
& IRT & 27 & 11,5 \\
& PNS & 4 & 1,7 \\
& Mahasiswa & 16 & 6,8 \\
& Pelajar & 1 & 0,4 \\
& WPS & 17 & 7,2 \\
& Tidak diketahui & 33 & 14,1 \\
\hline
\end{tabular}




\section{Regimen penggunaan Anti Retroviral (ARV)}

Hasil pada penelitian ini menunjukkan jumlah pasien berdasarkan penggunaan kombinasi antiretroviral pasien HIV/AIDS dirumah sakit dan puskesmas kota Samarinda memperlihatkan kombinasi terbanyak yang digunakan adalah $\mathrm{TDF}(300)+3 \mathrm{TC}(300)+\mathrm{EFV}(600)$ yaitu sebanyak 146 orang $(62,6 \%)$, $\mathrm{ZDV}+3 \mathrm{TC}(300 / 150)+\mathrm{NVP}(200)$

sebanyak 5 orang $(2,1 \%)$, dan $\mathrm{ZDV}+3 \mathrm{TC}(300 / 150)+\mathrm{EFV}(600)$

sebanyak 3 orang $(1,2 \%)$ yang bisa dilihat pada tabel 2 .

Tabel 2. Jumlah Pasien berdasarkan Regimen ARV pada HIV/AIDS di rumah sakit dan puskesmas kota Samarinda

\begin{tabular}{ccc}
\hline $\begin{array}{c}\text { Jenis Kombinasi } \\
\text { ARV }\end{array}$ & $\begin{array}{c}\text { Jumlah } \\
\text { Penggunaan }\end{array}$ & $\%$ \\
\hline TDF+3TC+EFV & 146 & 94,81 \\
ZDV+3TC+NVP & 5 & 3,24 \\
ZDV+3TC+EFV & 3 & 1.95 \\
\hline Total & 154 & 100 \\
\hline
\end{tabular}

Kombinasi obat ARV yang paling banyak digunakan pada rumah sakit dan puskesmas kota Samarinda yaitu Tenofovir-Lamivudin-Efavirenz karena kombinasi obat ini merupakan kombinasi pilihan pertama yang sudah ditetapkan oleh pemerintah untuk pasien HIV/AIDS. Hal ini sudah sesuai dengan yang direkomendasikan oleh WHO dan Depkes RI untuk regimen first-line ARV saat ini yaitu kombinasi 2 golongan Nucleoside Reverse Transciptase Inhibitor (NRTI) dan 1 Non-Nucleoside Reverse Tranciptase Inhibitor (NNRTI) yaitu fixed dose combination (FDC) yang sudah dalam satu tablet ARV. Adapun mekanisme dari NRTI ini yaitu obat pada golongan ini akan di ubah menjadi intraseluler dalam 3 tahap penambahan 3 gugus fosfat dan selanjutnya berkompetisi dengan natural nukleotida dan menghambat Reverse Transciptase sehingga perubahan RNA menjadi DNA terhambat. Selain itu NRTI juga menghentikan perpanjangan DNA. Mekanisme dari obat golongan NNRTI yaitu menghambat enzim reverse transcriptase dengan menginduksi perubahan konformasi yang menyebabkan inaktivasi enzim [8]. Dosis yang terkandung dalam satu tablet ARV adalah Tenofovir 300mg, Lamivudin 300mg, dan Efavirenz 600mg [2].

Selain regimen terapi ARV terdapat juga obat-obat lain yang dikonsumsi oleh penderita HIV/AIDS diantaranya kotrimoksazol, domperidon, dan fluconazol yang bisa dilihat pada tabel 3 .

Tabel 3. Regimen Penggunaan obat pendukung pada pasien HIV/AIDS (Non ARV)

\begin{tabular}{ccc}
\hline Nama obat & $\begin{array}{c}\text { Jumlah } \\
\text { Penggunaan }\end{array}$ & $(\%)$ \\
\hline kotrimoksazol & 42 & 18,02 \\
Fluconazol & 31 & 13,31 \\
Domperidon & 16 & 6,87 \\
Metoclopramid & 13 & 5,58 \\
Rifampicin & 11 & 4,72 \\
Etambutol & 11 & 4,72 \\
INH & 11 & 4,72 \\
Pyrazinamid & 11 & 4,72 \\
Lain-lain & 87 & 37,34 \\
\hline Total & 233 & 100 \\
\hline
\end{tabular}

Pasien dengan HIV positif mengalami infeksi oportunistik jika CD4 turun, salah satu infeksi oportunistik pada orang HIV ialah pheumocystic carinii pneumonia (PCP) jika jumlah CD4 kurang dari 200, PCP ini akan berdampak pada paru [10]. Untuk menghindari terjadinya infeksi oportunistik dapat dilakukan pencegahan/profilaksis, WHO 
sudah mengeluarkan pedoman yang ,mengusulkan penggunaan kotrimoksazol sebagai terapi profilaksis pada orang dengan HIV positif [1]. Jadi sesuai dengan data yang telah didapatkan bahwa pasien yang terinfeksi HIV di kota Samarinda telah diberikan terapi kotrimoksazol untuk mencegah terjadinya infeksi oportunistik pada pasien HIV. Penggunaan obat domperidon pada pasien HIV yaitu ditujukan untuk mengatasi efek samping yang disebabkan oleh beberapa obat yang dikonsumsi pasien HIV diantaranya efek samping yang disebabkan oleh obat Tenofovir dan Lamivudin dimana obat domperidon ini adalah obat yang di indikasikan sebagai antiemetik atau mual dan muntah yang bekerja sebagai pemblokir spesifik reseptor dopamin dan mempercepat peristaltik gastrointestinal yang menyebabkan pelepasan prolaktin. Obat fluconazol ialah obat yang di indikasikan sebagai antifungi yang efektif untuk penanganan infeksi mukosa topikal dan sistemik, yang disebabkan oleh candida atau jamur lain. Obat fluconazol ini bekerja dengan cara menghambat jamur lanosterol 14 alpha-demethylase yang kemudian akan mencegah pembentukan ergosterol yang merupakan komponen penting dalam membran sel jamur. Jadi bisa diasumsikan bahwa penggunaan obat fluconazol yaitu untuk terapi jamur yang disebabkan oleh infeksi oportunistik pada pasien dengan HIV/AIDS.

\section{KESIMPULAN}

Berdasarkan penelitian yang telah dilakukan maka dapat disimpulkan bahwa karakteristik pasien HIV/AIDS dominan adalah laki-laki (74,2\%), usia 25-49 tahun $(72,5 \%)$, tingkat pendidikan SMA $(21,4 \%)$ serta pekerjaan terbanyak pegawai swasta $(57,9 \%)$ dengan pola pengobatan fixed dose combination (FDC) yang telah menjadi satu tablet ARV.

\section{DAFTAR PUSTAKA}

[1] Taufany, Elly Febry dkk. 2018. Hubungan antara profilaksis kotrimoksazol dan prevalensi toksoplasmosis pada pasien HIV positif di Jember (The Association Between Phophylactic Cotrimoxazole and the Prevalece Toxoplasmosis in $H I V$-positive Patients in Jember). Ejurnal pustaka kesehatan, vol. 6 (no. 1).

[2] Wardani, Kusuma Putri dkk. 2017. Studi Efektivitas Antiretroviral Regimen Obat Kombinasi Dosis Tetap (Tenofovir/Lamivudin/ Efavirenz) Berdasarkan Peningkatan kadar Cd4 T-Limfosit. (Studi dilakukan di Instalasi Farmasi Rumah Sakit X Surabaya). Journal of pharmacy and science Vol. 2, No 1. P-ISSN: 2527-6328.

[3] Kementerian kesehatan RI. 2018. Laporan perkembangan HIV-AIDS dan infeksi menular seksual (IMS) triwulan 1. Kemenkes RI: Jakarta.

[4] Yuliandra, Yori dkk. 2017. Terapi antiretroviral pada pasien HIV/AIDS di RSUP. Dr. M. Djamil Padang: Kajian sosiodemografi dan evaluasi obat. Jurnal Sains \& Klinis. ISSN. 2407-7062, 4(1), 1-8.

[5] Widiyanti, Mirna, Sandy, Samuel, Fitriana, Eva. 2015. Dampak perpaduan obat Arv pada pasien HIV/AIDS ditinjau dari kenaikan jumlah limfosit CD4+ di RSUD. Dok II Kota Jayapura. PLASMA Vol. 1. No. 2.

[6] Saktina, Putri uli dkk. 2017. Karakteristik penderita AIDS dan infeksi oportunistik di rumah sakit umum pusat Sanglah Denpasar periode Juli 2013 sampai Juni 2014. E-Jurnal Medika, Vol 6 No 3.

[7] Kambu, Yowel dkk. 2016. Umur orang dengan HIV AIDS (ODHA) berhubungan dengan tindakan pencegahan penularan HIV. Jurnal keperawatan Indonesia, volum19 No. 3. 
[8] Depkes RI, 2006. Pedoman Pelayanan Kefarmasian Untuk Orang dengan HIV/AIDS (ODHA). Departemen Kesehatan Republik Indonesia. Jakarta.

[9] Nyoko, Yuneti Octavianus dkk. 2016. Karakteristik Penderita HIV/AIDS di Sumba Timur Tahun 2010-2016. Jurnal Kesehatan Primer, Vol. 1, Ed. 1.
[10] Yayasan Spiritia. 2014. Lembaran Informasi tentang HIV/AIDS untuk orang yang hidup dengan HIV/AIDS (ODHA). Lembaran Informasi 124 tes CD4: Spiritia.or.id. 